\title{
Copepods from ground waters of Western Australia, VI. Cyclopidae (Crustacea: Copepoda) from the Yilgarn Region and the Swan Coastal Plain
}

\author{
P. De Laurentiis ', G.L. Pesce ${ }^{1}$ and W.F. Humphreys ${ }^{2}$ \\ 'Dipartimento di Scienze Ambientali, University of L'Aquila, Via Vetoio, I-67100 L'Aquila, Italy \\ ${ }^{2}$ Western Australian Museum, Francis Street, Perth, Western Australia 6000, Australia
}

\begin{abstract}
Species of cyclopoid copepods collected from the Yilgarn Region included Halicyclops eberhardi sp. nov., Metacyclops cf. monacanthus Kiefer, 1928 and Microcyclops varicans (G. O. Sars, 1863). Metacyclops fiersi sp. nov. was recorded from the Swan Coastal Plain.

The discovery of Halicyclops eberhardi sp. nov. increases to five the number of congeners from Australia, the others being H. ambiguus Kiefer, 1967 from south-eastern Australia, H. longifurcatus Pesce et al., 1996 and H. spinifer Kiefer, 1935, both from the Cape Range, north-western Australia, and $H$. rochai De Laurentiis et al., 1999, from the Robe River Basin, Western Australia.

The discovery of Metacyclops fiersi sp. nov. and Metacyclops cf. monacanthus brings to five the number of species and subspecies of the genus from Australia, the others being $M$. arnaudi (G. O. Sars, 1908) and $M$. arnaudi platypus Kiefer, 1967, both from Victoria, and M. mortoni Pesce et al., 1996 , from north-western Australia.
\end{abstract}

\section{INTRODUCTION}

The groundwater of north-western Australia contain a diverse stygofauna that continues to surprise both as to its diversity and its affinities (Bradbury and Williams, 1997; Poore and Humphreys, 1998; Humphreys, 1999, 2000; Watts and Humphreys, 1999, 2000) including stygal copepods (Pesce et al., 1996a, 1996b; Pesce and De Laurentiis, 1996; De Laurentiis et al., 1999). This paper considers the cyclopids from some groundwater calcrete aquifers and near coastal aquifers in Western Australia, habitats that have been found to be especially rich in stygal species (Bradbury and Williams, 1997; Humphreys, 1999, 2001; Watts and Humphreys, 2000).

\section{Habitat and associated fauna}

\section{Swan Coastal Plain}

Metacyclops fiersi sp. nov. inhabits groundwater in the Eneabba area of the Swan Coastal Plain that lies west of the Gingin scarp, a wave-cut feature in the Archaean Yilgarn Craton. The coastal belt includes a lithified karstic eolianite, the Tamala Limestone, in which there are locally well developed cave systems. These Quaternary deposits overlie Mesozoic sediments. The superficial and confined groundwaters discharge to the ocean above a saltwater interface (Nidagal, 1994).

Of 13 ground water sites sampled, stygofauna was recovered from three bores and copepods from two, all of which were in or underlying the Tamala Limestone. No stygofauna was recovered from bores not associated with Tamala Limestone. In bore LS 26 (Nidagal, 1994) copepods were sampled from bores in both the superficial and confined aquifers, but, because the integrity of the bore casings is unknown, it is uncertain whether the copepods inhabit the confined aquifer.

Bore LS26 lies to the west of the Beagle Fault; LS26D is $35 \mathrm{~m}$ deep, is screened between 8-14 m AHD (Australian Height Datum) and had an initial salinity of 3510 TDS; LS26C is $100 \mathrm{~m}$ deep, is screened between 57-63 $\mathrm{m}$ AHD and had an initial salinity of 4430 TDS (Nidagal, 1994).

Bore LS30A lies north of the Beagle Fault and seaward of the saltwater interface. It is $20 \mathrm{~m}$ deep and is screened between 11-17 m AHD in Tamala Limestone overlying the saltwater interface and had an initial salinity of 4560 TDS (Nidagal, 1994). The copepods were in a sample taken in the top $5 \mathrm{~m}$ of the water column.

Stygofauna associated with $M$. fiersi sp. nov. were bathynellids and oligochaetes.

\section{Paroo}

The bores on Paroo Station tap a groundwater calcrete aquifer in the upper reaches of the Carey palaeodrainage channels in the Yilgarn Region of Western Australia. The characteristics of the Paroo area, the groundwater, and the origin of groundwater calcretes were covered by Watts and 
Humphreys $(1999,2000)$. This calcrete body is one of more than 210 such areas in the extensive palaeodrainage system of arid Australia (Humphreys, 1999), and each of the 15 areas examined to date has a unique fauna (Watts and Humphreys, 2000; Humphreys, 2000; unpublished).

Halicyclops eberhardi sp. nov. is known only from bore GSWA 15A where it occurs with a diverse stygofauna including Phreodrillidae (Oligochaeta), Bathynellidae (Syncarida: Bathynellacea), Candoninae (Ostracoda: Podocopida), Microcyclops varicans, Metacyclops cf. monacanthus (Copepoda: Cyclopidae), crangonyctoid Amphipoda, Nirridessus pulpa Watts and Humphreys, and Tjirtudessus eberhardi Watts and Humphreys (Coleoptera: Dytiscidae).

Metacyclops cf. monacanthus was found together with the taxa recorded sympatrically with $H$. eberhardi sp. nov. and, additionally, with Halicyclops eberhardi sp. nov. (Copepoda: Cyclopidae) and Kintingka kurutjutu Watts and Humphreys (Coleoptera: Dytiscidae).

Metacyclops varicans was found only in open pastoral. In this region Watts and Humphreys (2000) similarly found no stygal species of dytiscids, or other stygofauna in open large diameter pastoral wells, despite stygofauna being present in nearby narrow diameter bores.

\section{MATERIAL AND METHODS}

The samples were collected using haul nets and traps, largely down narrow bores and sometimes from pastoral wells of wide diameter $(>1 \mathrm{~m})$, as described elsewhere (Pesce et al., 1996). At some sites additional water quality data have subsequently been recorded (Watts and Humphreys, 2000). Samples were taken by haul net unless otherwise specified.

Permanent mounts were made in commercial polyvinyl-lactophenol medium. Dissected specimens were drawn at magnification of $400 \mathrm{x}$ and 1000x, the latter using an oil immersion lens and drawing tube mounted on a Leitz Laborlux D phase-contrast microscope. Type material is deposited in the Western Australian Museum (WAM). LS prefix for Leeman Shallow Drilling Project bores (Nidagal, 1994); GSWA: prefix for groundwater monitoring bores of the Western Australian Geological Survey; BES, prefix for field numbers of subterranean fauna collection at WAM. Terminology applied to body and appendages according to Huys and Boxshall (1991).

\section{SYSTEMATICS}

Family Cyclopidae Burmeister, 1834

Genus Halicyclops Norman, 1903
Halicyclops eberhardi sp. nov.

Figures 1-18

\section{Material Examined}

Holotype

\% (WAM C24700), Wiluna, bore GSWA 15A, haul net, Paroo Station, Western Australia, Australia (BES 6008), 26⒉ $22^{\prime} 2^{\prime \prime} S, 119^{\circ} 45^{\prime} 47^{\prime \prime} \mathrm{E}, 25$ June 1998, S.M. Eberhard.

\section{Paratypes}

Australia: Western Australia: 1 (WAM C24701), Wiluna, bore GSWA 15A, Paroo Station (BES 6008), 26 24'02"S, $119^{\circ} 45^{\prime} 47^{\prime \prime}$ E, 25 June 1998, S.M. Eberhard; 2 $q$ (WAM C24702), Wiluna, bore GSWA 15A, Paroo Station (BES 5988), 26²4'02"S, $119^{\circ} 45^{\prime} 47^{\prime \prime} \mathrm{E}, 24$ June 1998, S.M. Eberhard; 2 $\uparrow$ (WAM C24703), Wiluna, bore GSWA 6B, Paroo Station (BES 6030), 26 $26^{\circ} 02^{\prime \prime} \mathrm{S}, 119^{\circ} 46^{\prime} 38^{\prime \prime} \mathrm{E}, 25$ June 1998, S.M. Eberhard.

\section{Description}

\section{Female}

Length of holotype, excluding caudal setae, 450 $\mu \mathrm{m}$; length of paratypes 458-545 $\mu \mathrm{m}(\mathrm{n}=6)$. Prosome/urosome length ratio: 1.53-1.57 (Figure 1). Rostrum (Figure 14) subtriangular in frontal view, with 2 sensilla along posterior border. Sensilla present on dorsal surface of cephalothorax and subsequent thoracic somites.

Genital double-somite (Figures 1,3,4) about as wide as long, slightly wider than long in dissected specimens; two ovate pore depressions along ventrolateral borders. Seminal receptacle as in Figure 4. Hyaline fringes of genital double-somite and subsequent somites more coarsely crenulate dorsally than ventrally.

Anal somite (Figure 3) with pair of sensilla, operculum finely denticulate along posterior margin. Caudal rami (Figures 3,4) slightly longer than wide, with 6 setae. Posterolateral seta very long, more than 4 times longer than terminal accessory seta; dorsal seta about 5 times longer than caudal ramus; setation of outer and inner terminal setae as in Figure 2. Antennule (Figure 6) 6segmented; number of setation elements as follows: $8,12,5+1$ spine, $6+$ aesthetasc, $2,10+$ aesthetasc; most setae sparsely plumose.

Antenna (Figure 7): coxa reduced; basis with 2 inner plumose setae and one outer seta (vestigial exopod) overreaching tip of first endopodal segment, and a row of small cilia at the basis of inner margin; endopod segment 1 with 1 seta, segment 2 with 5 inner setae, 7 apical setae, and row of cilia on outer margin.

Labrum (Figure 12) with laterally serrate distal margin and row of 14 rounded teeth mid margin, 


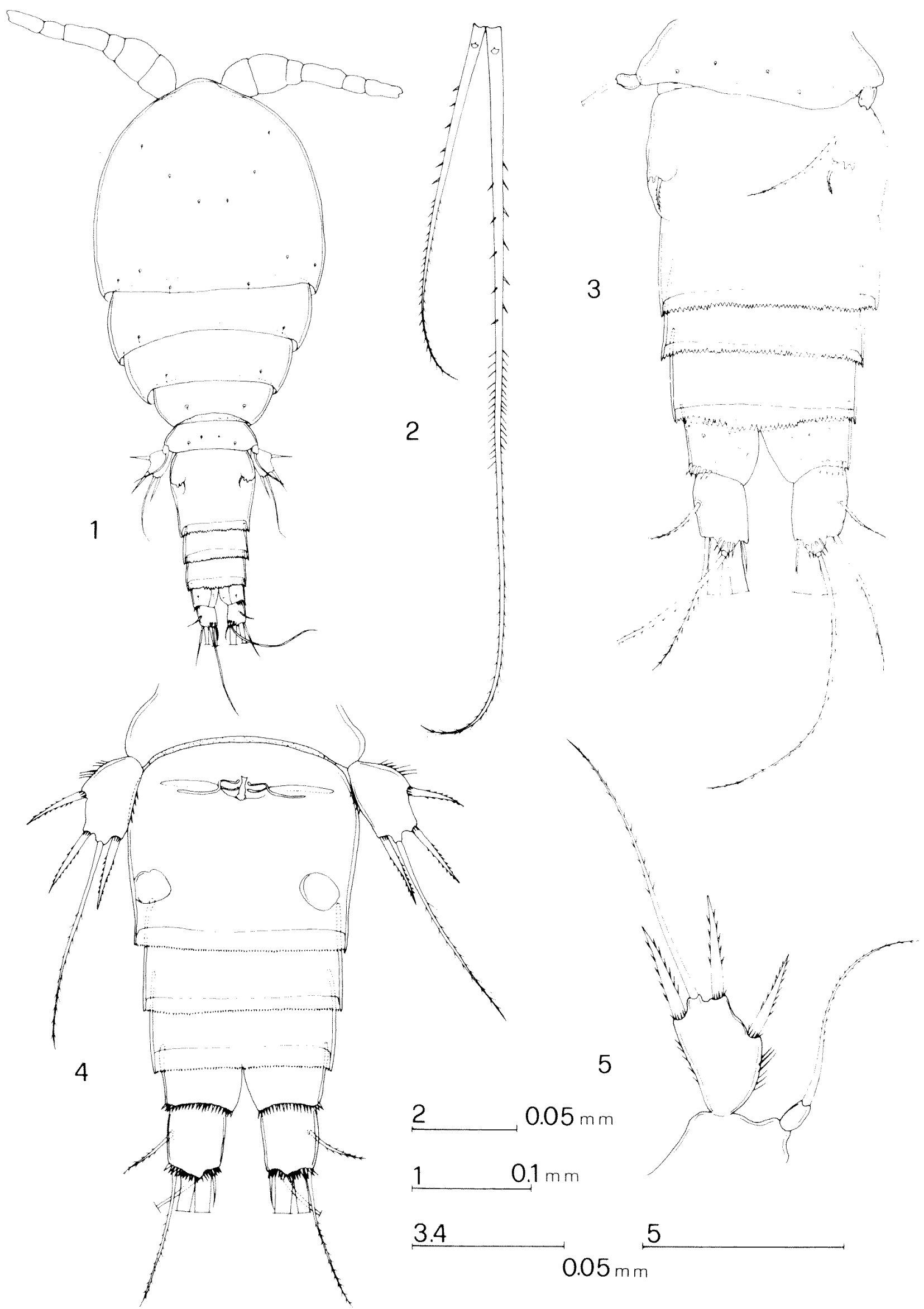

Figures 1-5 Halicyclops eberhardi sp. nov., 4 (holotype), 1-3, 5 (paratypes): 1, body; 2, furcal terminal setae; 3, abdomen and caudal rami (dorsal view); 4 , abdomen and caudal rami (ventral view); 5 , leg 5 . 


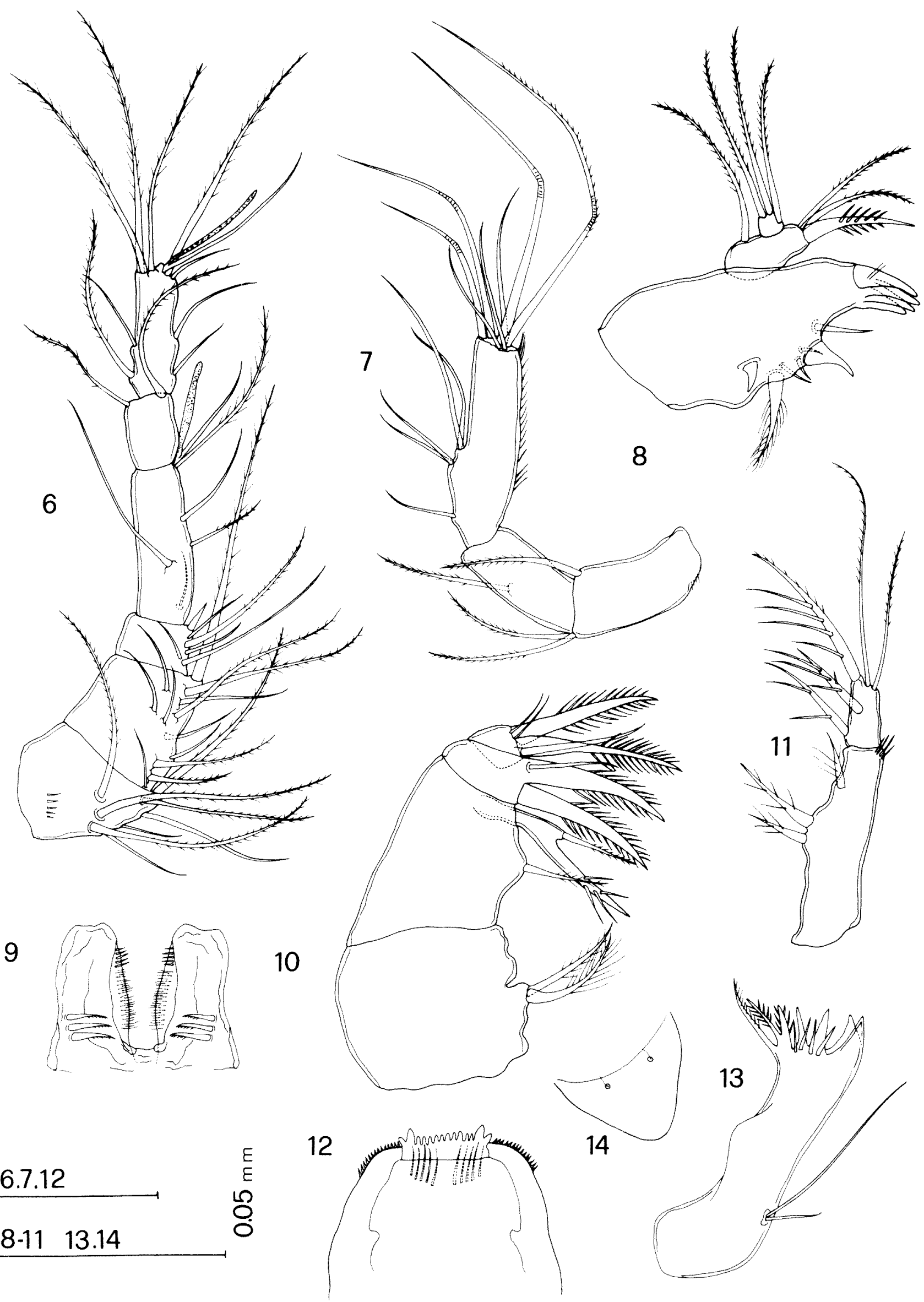

Figures 6-14 Halicyclops eberhardi sp. nov., 7,11,13 (holotype), 6, 8-10, 12, 14 (paratypes): 6, antennula; 7, antenna; 8, maxillula; 9 , paragnaths; 10 , maxilla; 11 , maxilliped; 12 , labrum; 13 , mandible; 14 , rostrum. 

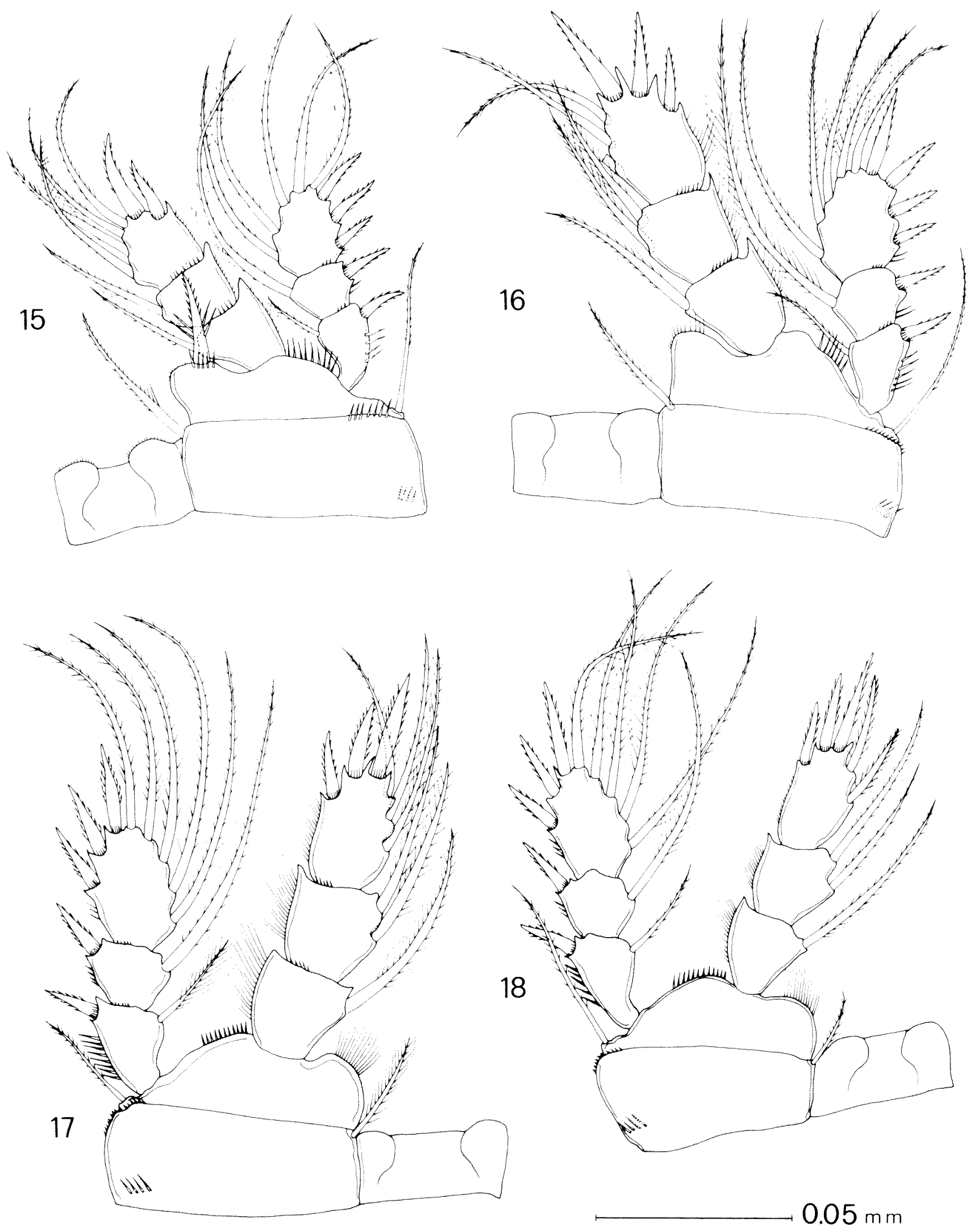

Figures 15-18 Halicyclops eberhardi sp. nov., 18 (holotype), 15-17 (paratypes): 15, leg 1; 16, leg 2;17, leg 3; $18, \operatorname{leg} 4$. 
outer teeth stouter; paired transverse rows of spinules on anterior surface.

Paragnaths (Figure 9) consisting of simple lobes bearing patches of fine setules and spinules, and 3 well developed pectinate setae.

Mandible (Figure 13) consisting of gnathobase and palp represented by 2 unequal setae implanted directly on coxa.

Maxillule (Figure 8) comprising praecoxa and 2segmented palp. Praecoxal arthrite armed with 4 spines, and 7 elements on inner surface. Palp comprising coxobasis with 1 spinulate spine and 2 setae distally, and 1 seta (representing exopod) on outer margin, and 1-segmented endopod bearing 3 long plumose setae.

Maxilla (Figure 10) 4-segmented; praecoxa with single distal endite armed with 2 elements; proximal coxal endite bearing single seta; distal coxal endite armed with 1 spine fused to endite and ornamented with 4 spinules, and 1 spine. Basis with endite bearing 2 stout elements and 1 seta. Endopod 1-segmented, bearing 2 setae, 1 normal and 2 stout spines.

Maxilliped (Figure 11) 2-segmented; proximal segment bearing 3 spiniform setae, terminal segment with 5 setae, 3 modified.

Legs 1-4 (Figures 15-18) armed as follows (Roman numerals representing spines; Arabic numerals setae):

\begin{tabular}{lllll}
\hline & COXA & BASIS & EXOPOD & ENDOPOD \\
\hline leg1 & $0-1$ & $1-\mathrm{I}$ & $\mathrm{I}-1 ; \mathrm{I}-1 ; \mathrm{III}+1,4$ & $0-1 ; 0-1 ; \mathrm{I}, \mathrm{I}+1,3$ \\
$\operatorname{leg} 2$ & $0-1$ & $1-0$ & $\mathrm{I}-1 ; \mathrm{I}-1 ; \mathrm{II}, \mathrm{I}+1,4$ & $0-1 ; 0-2 ; \mathrm{I}, \mathrm{II}, 3$ \\
$\operatorname{leg} 3$ & $0-1$ & $1-0$ & $\mathrm{I}-1 ; \mathrm{I}-1 ; \mathrm{II}, \mathrm{I}+1,4$ & $0-1 ; 0-2 ; \mathrm{I}, \mathrm{II}, 3$ \\
$\operatorname{leg} 4$ & $0-1$ & $1-0$ & $\mathrm{I}-1 ; \mathrm{I}-1 ; \mathrm{II}, \mathrm{I}+1,4$ & $0-1 ; 0-2 ; \mathrm{I}, \mathrm{II}, 2$ \\
\hline
\end{tabular}

Intercoxal sclerite of leg 1 with rows of thin cilia, spine at inner corner of leg 1 basis (Figure 15) reaching about tip of endopod 2; intercoxal sclerites of legs 2 to 4 , naked.

Leg 4 endopod 3 (Figure 18) less than twice as long as wide; inner apical spine as long as segment, both inner setae spiniform.

Leg 5 (Figure 5) exopod 1.5 times longer than wide, armed with 3 spines, all slightly shorter than segment, and 1 long seta, more than twice as long as segment; dorsal remnant seta long and plumose.

Leg 6 (Figure 3) rudimentary, consisting of 2 blunt elements and plumed seta.

Male

Unknown.

\section{Affinities}

Besides $H$. eberhardi sp. nov. the following species and subspecies are described as having a spine formula of legs 1-4 exopod 3: 3433: $H$. brevispinosus meridionalis Herbst, 1953, from Romania, the Black
Sea and the Azov Sea; H. laminifer Herbst, 1982, from the U.S.A.; H. tetracanthus Rocha, 1955, from Belize; H. sinensis (Kiefer, 1928) from China and Japan; and $H$. exiguus sensu Defaye and Dussart, 1988, from French Guyana (this last species, on account of the peculiar spine formula of the exopod 3 of legs 1-4, and other minor differences as compared to $H$. exiguus Kiefer, 1934, from Haiti and Costa Rica, may represent a new species, and this opinion is shared by Rocha, in litt.).

Within the above group the most morphologically similar species seems to be $H$. tetracanthus. Particularly with this species $H$. eberhardi sp. nov. shares the remarkable length of the seta on the exopod of leg 5, as well as the length of the dorsal caudal seta and the length ratio between the posterolateral seta and caudal ramus. It differs in other characteristics, such as the presence of a vestigial exopodal seta on the antenna (versus seta absent), the armature of the intercoxal sclerites of legs $1-4$, the presence of 3 spines on the endopod 3 of legs 2-3 (versus 4 spines), the length of the caudal rami (slightly longer than wide in $H$. eberhardi, 1.5 times wider than long in $H$. tetracanthus), and the length of the terminal accessory seta.

From the other species in the same group, notwithstanding the inadequate description and illustrations of $H$. sinensis and $H$. brevispinosus meridionalis, the new species is easily distinguishable by a combination of characteristics, viz. the anal pseudo-operculum, the length of the spine on the leg 1 basis, the length of the inner spine of the leg 4 endopod 3 , and the general armature of the caudal rami.

\section{Etymology}

The species is named for Stefan M. Eberhard, who collected the new species.

\section{Genus Metacyclops Kiefer, 1927 \\ Metacyclops fiersi sp. nov. Figures 19-35}

\section{Material Examined}

Holotype

ๆ (WAM C24704), Eneabba, bore LS30A, Western Australia, Australia (BES 5957), 29²6'00"S, $115^{\circ} 00^{\prime} 00^{\prime \prime E}, 4$ June 1998, S.M. Eberhard.

\section{Paratypes}

Australia: Western Australia: $2 \uparrow q, 1 \delta$ (WAM C24705), Eneabba, bore LS30A (BES 5957), $29^{\circ} 26^{\prime} 00^{\prime \prime} \mathrm{S}, 115^{\circ} 00^{\prime} 00^{\prime \prime} \mathrm{E}, 4$ June 1998, S.M. Eberhard; 1 \& (WAM C24706), Eneabba, bore LS26C, (BES

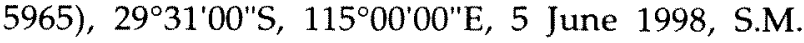
Eberhard; 2 \& (WAM C24707), Eneabba, bore 


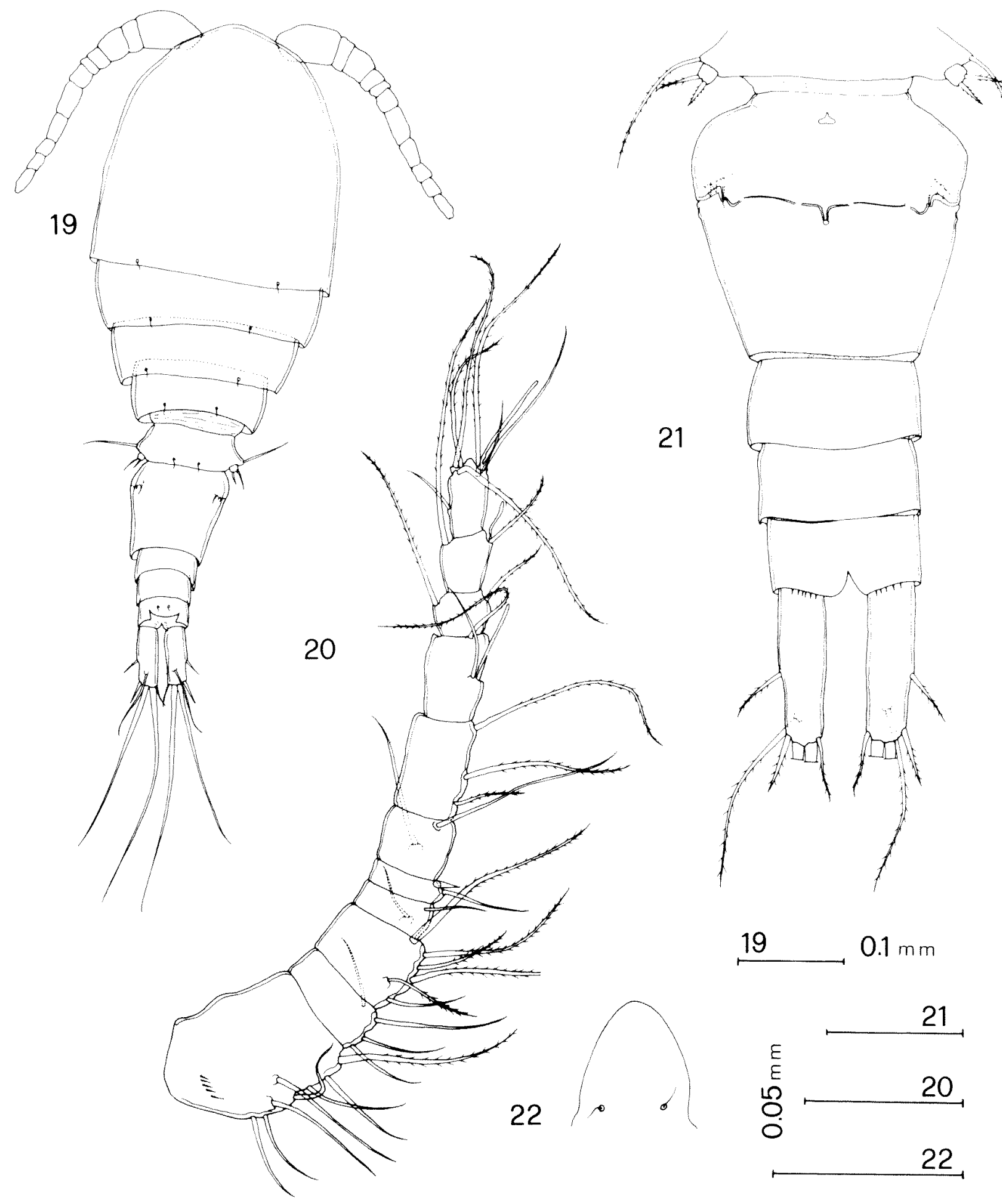

Figures 19-22 Metacyclops fiersi sp. nov., 19 (holotype), 20-22 (female paratypes): 19, body; 20, antennula; 21, abdomen and caudal rami (ventral view); 22, rostrum.

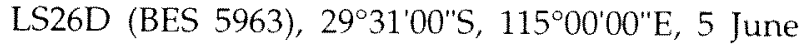
1998, S.M. Eberhard.

\section{Description}

Female

Length of holotype, excluding caudal setae, 731 $\mu \mathrm{m}$; paratypes 630-844 $\mu \mathrm{m} \quad(n=6)$. Prosome/ urosome length ratio: 1.54-1.57 (Figure 19).
Rostrum (Figure 22) subtriangular in frontal view, with 2 sensilla along posterior border. First pedigerous somite fused with cephalosome forming cepaholthorax. Sensilla present on dorsal surface of cephalothorax.

Genital double-somite (Figures 19, 21) slightly longer than wide; Seminal receptacle not well visible. Genital double-somite and subsequent somites smooth dorsally and ventrally. 


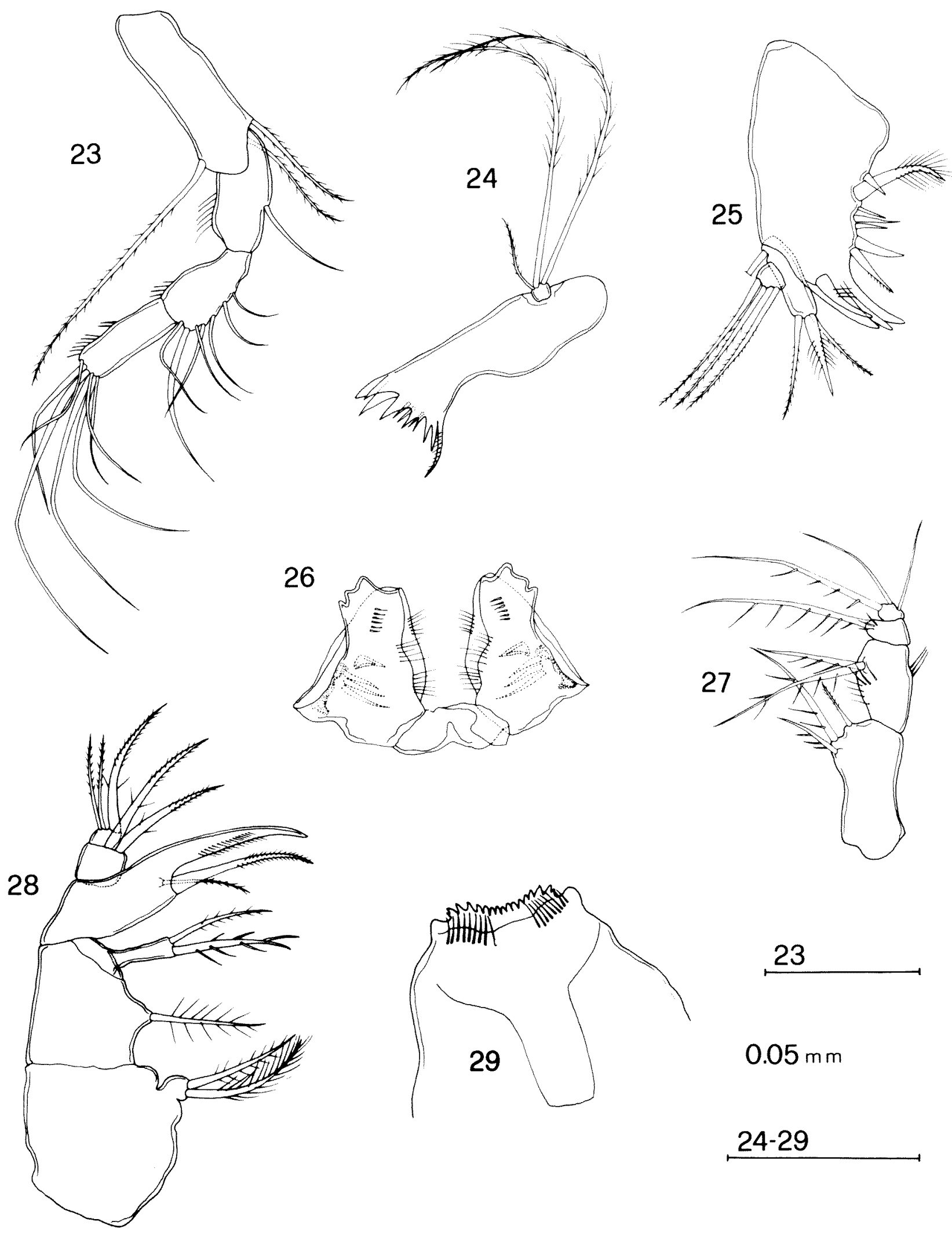

Figures 23-29 Metacyclops fiersi sp. nov., 23, 27-29 (holotype), 24-26 (female paratypes): 23, antenna; 24, mandible; 25, maxillula; 26, paragnaths; 27 , maxilliped; 28 , maxilla; 29 , labrum. 

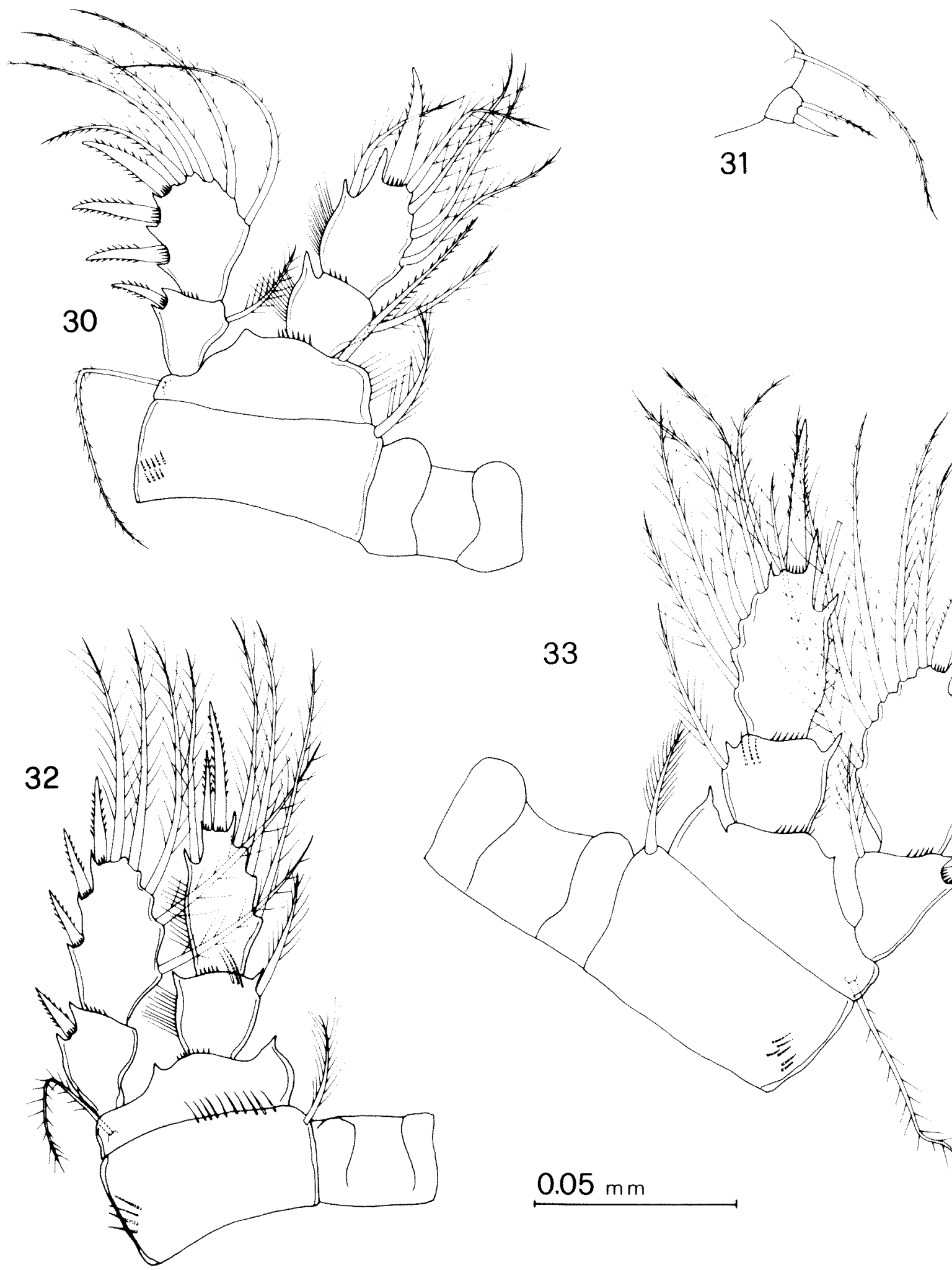

Figures 30-33 Metacyclops fiersi sp. nov., 30, 32 (holotype), 31, 33 (female paratypes): 30, leg 1; 31, leg 5; 32, leg 4; 33, $\operatorname{leg} 2$.

Anal somite (Figures 19, 21) bearing row of spinules along posteroventral margin and 1 pair of dorsal sensilla.

Caudal rami (Figures 19, 21) longer than wide (L/ $1=3.20-3.28$ ), with 6 setae. Posterolateral seta slightly shorter than terminal accessory seta; dorsal seta about 1.25 times longer than caudal ramus. Antennule (Figure 20) 11-segmented; number of setation elements as follows: $8,4,6,2,1+$ spine, 2 , 3,2 + aesthetasc, 2, 2 + aesthetasc, 7 + aesthetasc; most setae sparsely plumose.

Antenna (Figure 23): basis with 2 inner plumose 

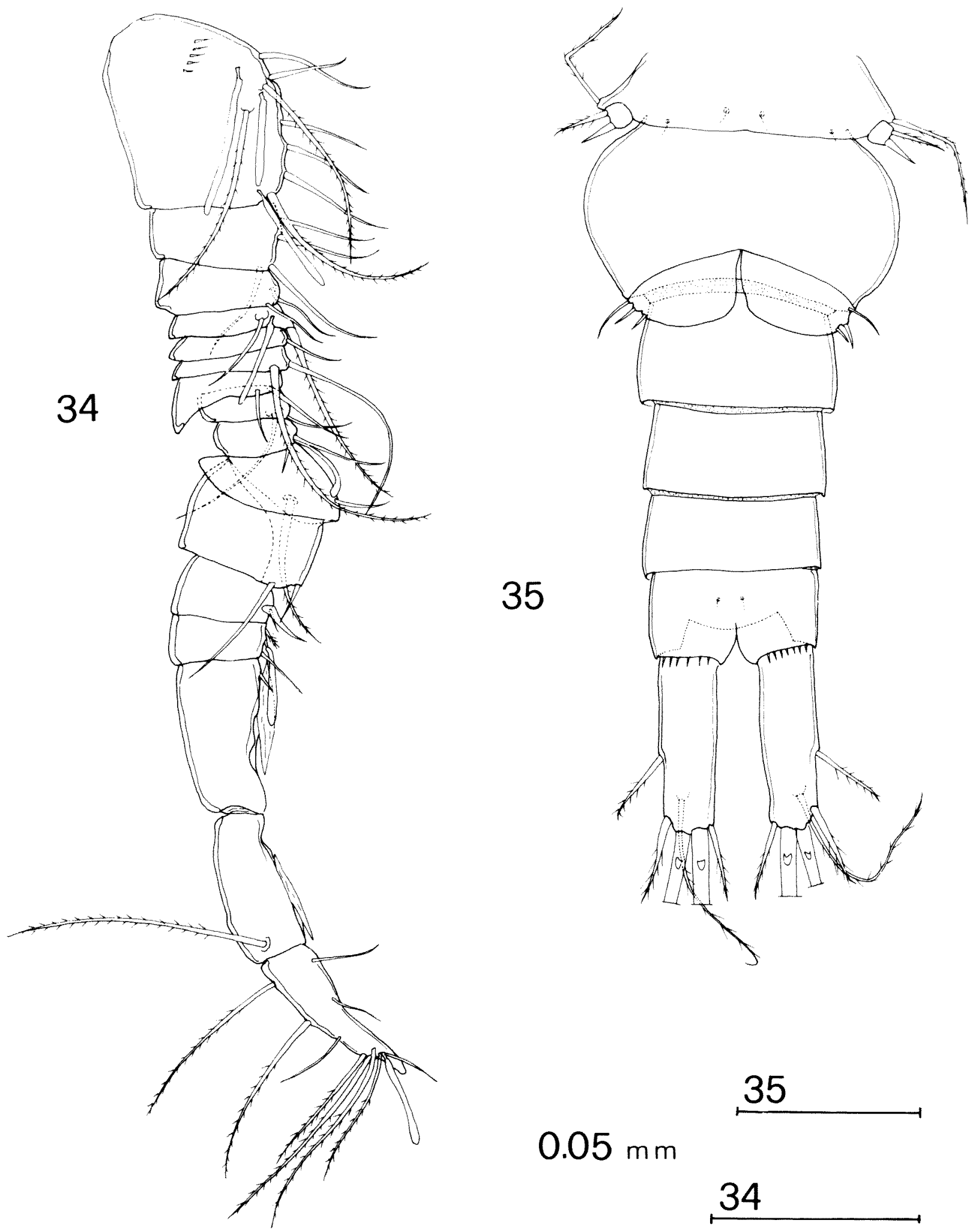

Figures 34-35 Metacyclops fiersi sp. nov., male paratype: 34, antennula; 35, abdomen and caudal rami (ventral view).

setae and 1 outer seta (vestigial exopod) overreaching tip of distal endopodal segment, remaining ornament not clearly visible; endopod segment 1 with 1 seta, segment 2 with 7 inner setae, 7 apical setae, and row of cilia on outer margin.
Labrum (Figure 29) with strong teeth in mid of posterior margin; paired transverse rows of setules on anterior surface.

Paragnaths (Figure 26) consisting of lobes bearing patches of fine setules and spinules, and 4 well developed setae, one stouter and spiniform. 
Mandible (Figure 24) consisting of gnathobase and palp bearing 2 long and 1 shorter setae.

Maxillule (Figure 25 ) comprising praecoxa and 2segmented palp. Praecoxal arthrite armed with 8 spines, one setulose, and 3 spines fused to segment. Palp comprising coxobasis with 1 setulose spine and 2 setae distally, and 1 seta (representing exopod) on outer margin; 1-segmented endopod bearing 3 long plumose setae.

Maxilla (Figure 28): praecoxa with single distal endite armed with 2 setiform elements; proximal coxal endite bearing single seta; distal coxal endite armed with 1 seta and one stronger element armed with several thin spinules. Basis with endite bearing 2 stout elements and 1 seta. Endopod 2-segmented, first segment bearing 2 spiniform setae, distal one with 3 setae, one spiniform.

Maxilliped (Figure 27) 4-segmented; syncoxa bearing 3 setae, 2 spinulose; basis with 2 spinulose setae and rows of thin setules both on inner and outer margins; first endopodal segment bearing single spinulose seta and spinules around base; second endopodal segment with long spinulose seta and 2 thin unarmed setae.

Legs 1-4 (Figures 30, 32-33) armed as follows (Roman numerals representing spines; Arabic numerals setae):

\begin{tabular}{lllll}
\hline & COXA & BASIS & EXOPOD & ENDOPOD \\
\hline leg1 & $0-1$ & $1-\mathrm{I}$ & $\mathrm{I}-1 ; \mathrm{III}, 2,3$ & $0-1 ; 1, \mathrm{I}+1,3$ \\
$\operatorname{leg} 2$ & $0-1$ & $1-0$ & $\mathrm{I}-1 ; \mathrm{III}, \mathrm{I}+1,4$ & $0-1 ; 1, \mathrm{I}+1,4$ \\
$\operatorname{leg} 3$ & $0-1$ & $1-0$ & $\mathrm{I}-1 ; \mathrm{III}, \mathrm{I}+1,4$ & $0-1 ; 1, \mathrm{I}+1,4$ \\
$\operatorname{leg} 4$ & $0-1$ & $1-0$ & $\mathrm{I}-0 ; \mathrm{II}, \mathrm{I}+1,4$ & $0-1 ; 1, \mathrm{II}, 3$ \\
\hline
\end{tabular}

Intercoxal sclerites naked. Spine at inner corner of leg 1 basis (Figure 30) reaching tip of endopod 2.

Leg 4 endopod 2 (Figure 32) about twice as long as wide, with 2 apical spines; inner spine slightly shorter than segment.

Leg 5 (Figure 31) exopod slightly wider than long, armed with 1 distal spine longer than segment, and 1 distal seta about 1.6 longer than spine; dorsal remnant seta long and plumose.

Leg 6 (Figure 21) rudimentary, consisting of 2 blunt elements and 1 seta.

\section{Male}

Length $598 \mu \mathrm{m}$. Differences from female include 16-segmented and prehensile antennula (Figure 34), and leg 6 with 3 appendages, outer longest (Figure 35).

\section{Affinities}

Three described species of Metacyclops ( $M$. chelazzii Dumont, 1981 from Somalia, M. mutatus Herbst, 1988 from Aruba, West Indies, and $M$. micropus Kiefer, 1932 from the Ivory Coast) share the combination of the following characteristics: spine formula of exopod 3 of the swimming legs 3443 , very short seta and a rather long spine on the exopod of leg 5, 11-segmented antennula and 2 apical spines on the distal segment of leg 4 endopod.

The new species is easily distinguishable from the above species as follows: from $M$. chelazzii mostly by its unornamented intercoxal sclerites (versus armed with a row of spinules); the length ratio between the terminal accessory and the posterolateral setae (about 1: 1.3 in chelazzii, $1.1: 1.0$ in fiersi), and length of dorsal seta compared to the terminal accessory seta (3:1 in fiersi, 1:1 in chelazzii); from $M$. mutatus by presence of spine on basis of leg 1 (versus spine absent), by the length of the distal inner spine of leg 4 endopod (slightly shorter than segment and 1.75 longer than outermost in fiersi; much longer than segment and about twice as long as outermost in mutatus), and the length of caudal dorsal seta compared to the terminal accessory seta (3:1 in fiersi, 1:1 in mutatus); from $M$. micropus by length of endopod 3 of leg 4 (about twice as long as wide in fiersi, 1.1 in micropus), length of caudal ramus (3 times longer than wide in fiersi, about twice as long as wide in micropus), and length of dorsal seta compared to the terminal accessory seta (3:1 in fiersi, $2: 1$ in micropus).

The groundwater cyclopoid fauna of Western Australia, with the single exception of the genus Diacyclops, comprises species belonging to genera such as Halicyclops, Paracyclops, Metacyclops, Mesocyclops, Microcyclops and Apocyclops, which comprise largely stygophilic or surface species. The cyclopoid copepod fauna inhabiting groundwaters of Western Australia, in contrast to the harpacticoid copepods, seems to lack true stygobiontic genera such as Haplocyclops, Speocyclops, Graeteriella, etc., or equivalent undescribed genera.

\section{Etymology}

The species is named for the eminent copepodologist Frank Fiers.

\section{Metacyclops cf. monacanthus Kiefer, 1928}

Figures 36-52

\section{Material Examined}

Australia: Western Australia: $4 q q$ (WAM C24708), Wiluna, bore GSWA 6B, Paroo Station,

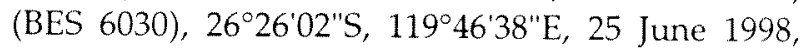
S.M. Eberhard; 3 q 9 , (WAM C24709), Wiluna, bore GSWA 15C, trap, Paroo Station (BES 6004), $26^{\circ} 24^{\prime} 02^{\prime \prime} \mathrm{S}, 119^{\circ} 45^{\prime} 47^{\prime \prime} \mathrm{E}, 25$ June 1998, S.M. Eberhard; 1 \& (WAM C24710), Wiluna, bore GSWA 5B, Paroo Station (BES 6031), 26 26.25"S, 119 46'19"E, 25 June 1998, S.M. Eberhard; 1 ? (WAM C24711), Wiluna, bore GSWA 15A, trap, 


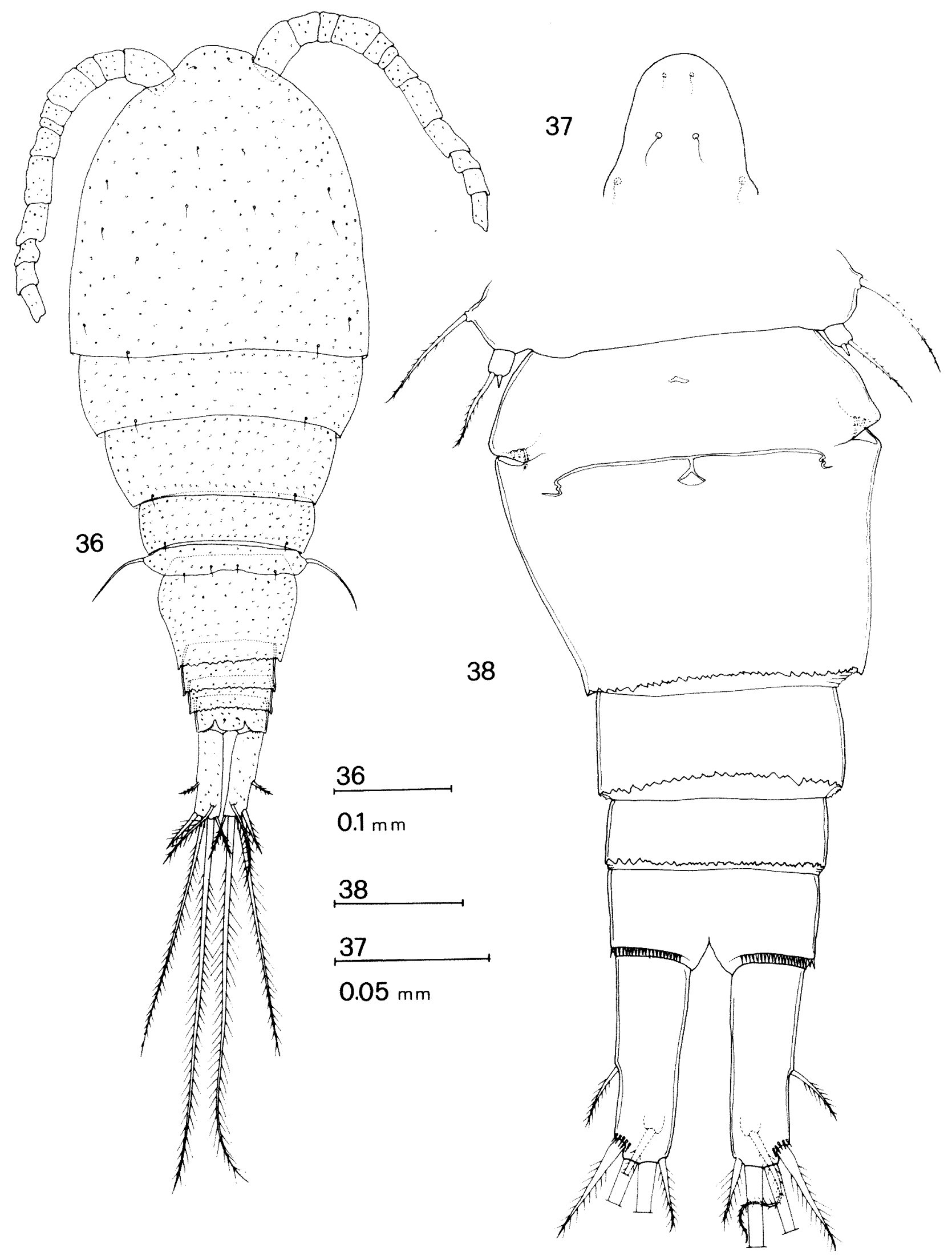

Figures 36-38 Metacyclops cf. monacanthus female: 36, body; 37, rostrum; 38, abdomen and caudal rami (ventral view). 


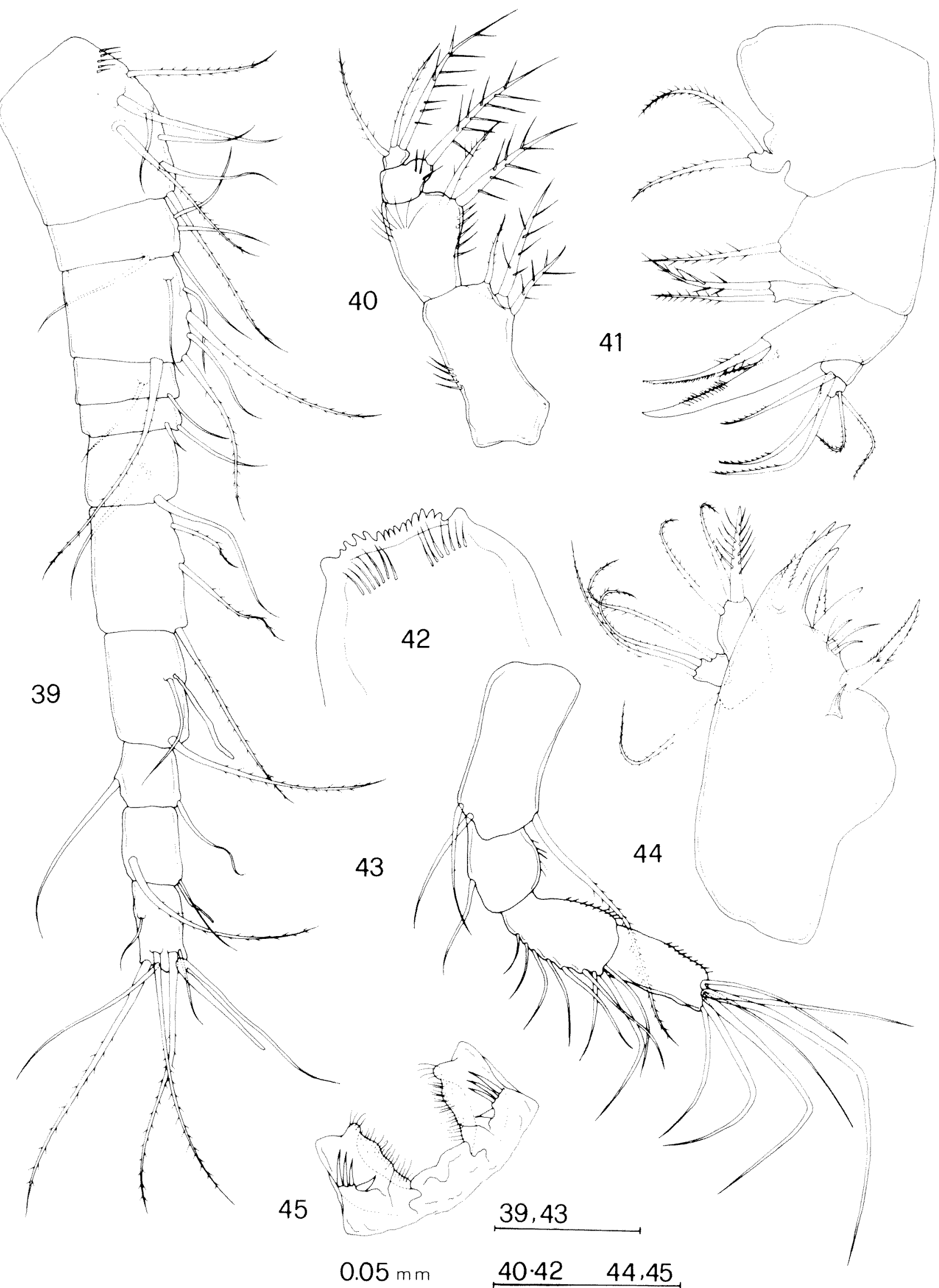

Figures 39-45 Metacyclops cf. monacanthus female: 39, antennula; 40, maxilliped; 41, maxilla; 42, labrum; 43, antenna; 44, maxillula; 45 , paragnaths. 
Paroo Station (BES 5998), 26 24'02"S, $119^{\circ} 45^{\prime} 47^{\prime \prime} \mathrm{E}$, 25 June 1998, S.M. Eberhard; $7 q q, 5$ ơ $\delta$ (WAM C24712),Wiluna, bore GSWA 6C, Paroo Station (BES

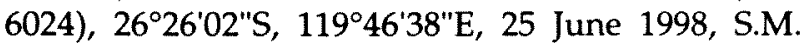
Eberhard; 1 o (WAM C24713),Wiluna, bore GSWA 15A, Paroo Station (BES 6008), 26 24.02"S, $19^{\circ} 45^{\prime} 47^{\prime \prime} \mathrm{E}, 25$ June 1998, S.M. Eberhard; 9 $\%, 1$ 万, 3 juv. (WAM C24714), Wiluna, bore GSWA 6A, Paroo Station (BES 6019), 26 26'02"S, 119 $46^{\prime} 38^{\prime \prime} \mathrm{E}$, 25 June 1998, S.M. Eberhard; 5 \&, 1 juv. (WAM C24715),Wiluna, bore GSWA 16, Paroo Station (BES 5996), 26 $25^{\prime} 31^{\prime \prime S}, 119^{\circ} 43^{\prime} 43^{\prime \prime} \mathrm{E}, 24$ June 1998, S.M. Eberhard.

\section{Description}

\section{Female}

Length, excluding caudal setae, 680-1036 $\mu \mathrm{m}$ $(n=31)$. Body and appendages dorsally and ventrally covered by numerous small pits (Figure 36). Prosome/urosome length ratio: 1.8-2.0. Rostrum (Figure 37) subtriangular in frontal view, with 6 sensilla. First pedigerous somite fused with cephalosome forming cepaholthorax. Sensilla present on dorsal surface of cephalothorax.

Genital double-somite (Figures 36, 38) about as long as wide. Seminal receptacle not clearly visible. Genital double-somite and subsequent somites with hyaline membrane irregularly serrated, both dorsally and ventrally.

Anal somite (Figures 36, 38) bearing row of spinules along posteroventral margin and pair of dorsal sensilla.

Caudal rami (Figures 36, 38) longer than wide (L/ $1=3.20-3.60$ ), with 6 setae. Posterolateral seta longer than terminal accessory seta; dorsal seta about as long as caudal ramus. Antennule (Figure 39) 11segmented; number of setation elements as follows: $7,4,6,2,2,2,3,2+$ aesthetasc, 2, 2 + aesthetasc, $7+$ aesthetasc; most setae sparsely plumose.

Antenna (Figure 43): basis with 2 inner setae and 1 outer plumose seta (vestigial exopod) reaching tip of distal endopodal segment, remaining ornament not clearly visible; endopod segment 1 with 1 seta, segment 2 with 9 inner setae, 7 apical setae, and row of cilia on outer margins.

Labrum (Figure 42) with strong teeth midway along posterior margin; paired transverse rows of setules on anterior surface.

Paragnaths (Figure 45) consisting of lobes bearing patches of fine setules, and 4 well developed setae, one stouter and spiniform.

Mandible (Figure 46) consisting of gnathobase and palp bearing 2 long and 1 shorter setae.

Maxillule (Figure 44 ) comprising praecoxa and 2segmented palp. Praecoxal arthrite armed with 8 spines, 1 finely setulose, and 3 spines fused to segment. Palp comprising coxobasis with 1 setulose spine and 2 setae distally, and 1 seta (representing exopod) on outer margin; 1-segmented endopod bearing 3 long plumose setae.

Maxilla (Figure 41): praecoxa with single distal endite armed with 2 setiform elements; proximal coxal endite bearing single seta; distal coxal endite armed with 1 seta and one stronger element armed with several thin spinules. Basis with endite bearing 2 stout elements and 1 seta. Endopod 2-segmented, first segment bearing 2 spiniform setae, distal one with 3 setae, 1 spiniform.

Maxilliped (Figure 40) 4-segmented; syncoxa bearing 3 setae, 2 spinulose, and row of spinules along outer margin; basis with 2 spinulose setae and rows of thin setules on both inner and outer margins; first endopodal segment bearing 1 spinulose seta and spinules around base; second endopodal segment with long spinulose seta and 2 plumose setae.

Legs 1-4 (Figures 47-49) armed as follows (Roman numerals representing spines; Arabic numerals setae):

\begin{tabular}{lllll}
\hline & COXA & BASIS & EXOPOD & ENDOPOD \\
\hline leg1 & $0-1$ & $1-\mathrm{I}$ & $\mathrm{I}-1 ; \mathrm{III}, 2,3$ & $0-1 ; 1, \mathrm{I}+1,3$ \\
leg2 & $0-1$ & $1-0$ & $\mathrm{I}-1 ; \mathrm{II}, \mathrm{I}+1,4$ & $0-1 ; 1, \mathrm{I}+1,4$ \\
leg3 & $0-1$ & $1-0$ & $\mathrm{I}-1 ; \mathrm{II}, \mathrm{I}+1,4$ & $0-1 ; 1, \mathrm{I}+1,4$ \\
leg4 & $0-1$ & $1-0$ & $\mathrm{I}-0 ; \mathrm{II}, \mathrm{I}+1,4$ & $0-1 ; 1, \mathrm{I}, 3$ \\
\hline
\end{tabular}

Spine at inner corner of leg 1 basis (Figure 47) reaching tip of endopod 2.

Intercoxal sclerites naked. Leg 4, posterior coxa with 4 rows of spinules; endopod 2 (Figure 49) about twice as long as wide, with one apical spine, about as long as segment.

Leg 5 (Figure 38) exopod about as long as wide, armed with 1 distal spine, much shorter than segment, and 1 long distal plumose seta.; dorsal remnant seta long and plumose.

Leg 6 (Figure38) rudimentary, consisting of 2 blunt elements and 1 seta.

Male

Length, excluding caudal setae, 651-839 $\mu \mathrm{m}$ $(\mathrm{n}=8)$. Prosome/urosome length ratio: 1.5-1.7 (Figure 50). Differences with female include 16segmented and prehensile antennula (Figure 52), and leg 6 with 3 subequal appendages, innermost spiniform (Figure 51).

\section{Remarks}

In most respects the material examined fits the original description and the few figures of $M$. monacanthus by Kiefer (1928) from New Zealand. The only difference recorded in the material from Western Australia is the presence of hyaline fringes along the posterior border of the genital double somite and subsequent somites, except the anal one (versus the same somites seemingly naked).

However, notwithstanding critical examination of 


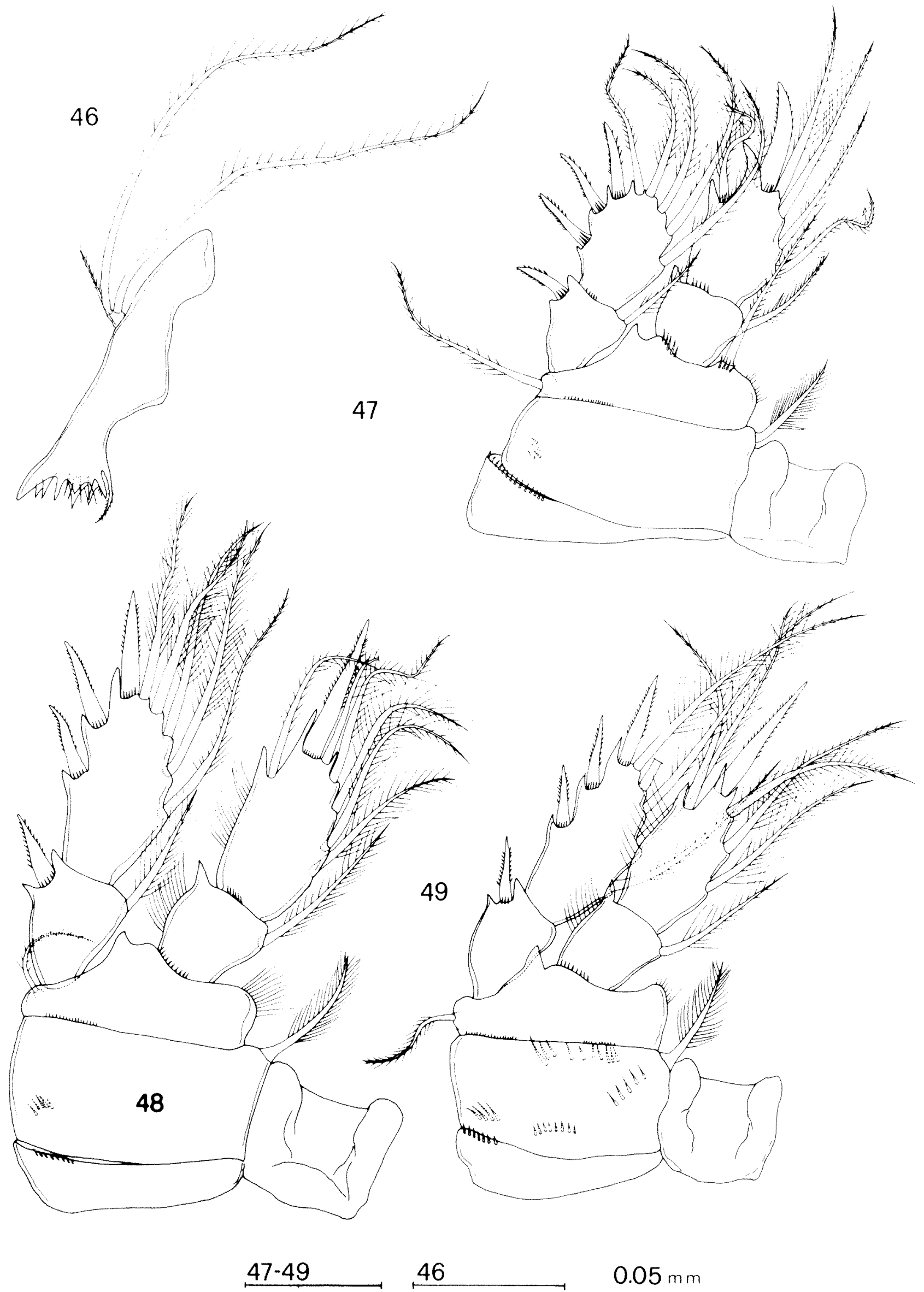

Figures 46-49 Metacyclops cf. monacanthus female: 46, mandible; 47, leg 1; 48, leg 3;49, leg4. 


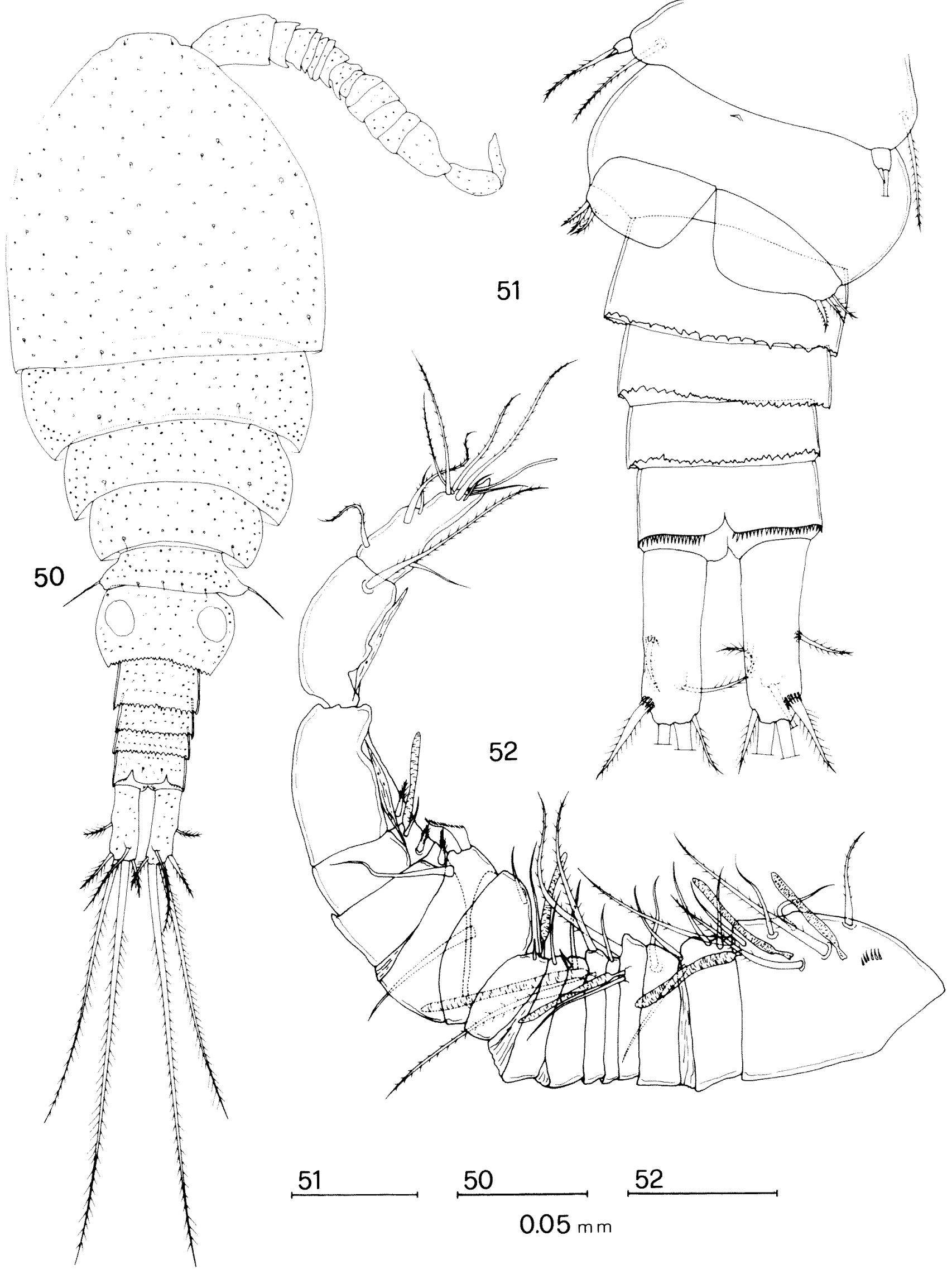

Figures 50-52 Metacyclops cf. monacanthus male: 50, body; 51, abdomen and caudal rami (ventral view); 52, antennula. 
the characteristics, at present it is impossible to assign the specimens to the above species with certainty, owing to the inadequate and incomplete description and illustrations by Kiefer, as well as to the distribution of the two species, and the impossibility of obtaining type-material from the Kiefer Collection at the Karlsruhe Museum (Germany).

\section{Genus Microcyclops Claus, 1893}

\section{Microcyclops varicans (G.O. Sars, 1863)}

\section{Material Examined}

Australia: Western Australia: $2 q q$ (WAM C24716), Wiluna, bore GSWA 15A, Paroo Station (BES 6008), 29²4'02"S, 11945'47"E, 25 June 1998, S.M. Eberhard; 2 \& (WAM C24717), Wiluna, Pharlap Well, Paroo Station (BES 6055), 26¹6 $50^{\prime \prime} S$, 119³5'08"E, 26 June 1998, S.M. Eberhard; 2 우, 1 juv. (WAM C24718), Wiluna, Comic Court Well, Paroo Station (BES 6068), 26 20 $53^{\prime \prime} \mathrm{S}, 119^{\circ} 39^{\prime} 17^{\prime \prime} \mathrm{E}$, 26 June 1998, S.M. Eberhard.

\section{ACKNOWLEDGEMENTS}

We thank Stefan Eberhard who conducted the sampling, the lessees of Paroo Station for access to the bores, and Neil Holmes of the Water and Rivers Commission for providing access information to bore sites.

\section{REFERENCES}

Bradbury, J.H. and Williams, W.D. (1997). Amphipod (Crustacea) diversity in underground waters in Australia: an Aladdin's Cave. Memoirs of the Musetm of Victoria 56: 513-519.

De Laurentiis, P., Pesce, G.L. and Humphreys, W.F. (1999). Copepods from ground waters of Western Australia, IV. Cyclopids from basin and craton aquifers (Crustacea: Copepoda: Cyclopidae). Records of the Western Australian Museum 19: 243-257.

Humphreys, W.F. (1999). Relict stygofaunas living in sea salt, karst and calcrete habitats in arid northwestern Australia contain many ancient lineages. Pp. 219-227 in W. Ponder and D. Lunney (eds) The Other $99 \%$. The Conservation and Biodiversity of Invertebrates.
Transactions of the Royal Zoological Society of New South Wales, Mosman 2088.

Humphreys, W.F. (2000). Chapter 30. The hypogean fauna of the Cape Range peninsula and Barrow Island, northwestern Australia: 587-607. In $\mathrm{H}$. Wilkens, D.C. Culver and W.F. Humphreys (eds), Ecosystems of the World, vol. 30. Subterranean Ecosystems. Elsevier, Amsterdam.

Humphreys, W.F. (2001). Groundwater calcrete aquifers in the Australian arid zone: an unfolding plethora of stygal diversity. Records of the Western Australian Museum Supplement No. 64: 63-83.

Huys, R. and Boxshall, G. A. (1991). Copepod Evolution. The Ray Society, London. pp.468.

Nidagal, V. (1994). Hydrogeology of the coastal plain between Leeman and Dongara, Perth Basin. Western Australia Geological Survey, Record 1994/10.

Pesce, G. L. and De Laurentiis P. (1996). Copepods from ground waters of Western Australia. III. Diacyclops humphreysi n. sp. and comments on the Diacyclops crassicaudis-complex (Copepoda: Cyclopidae). Crustaceana 69: 524-531.

Pesce, G.L., De Laurentiis, P. and Humphreys, W.F. (1996a). Copepods from ground waters of Western Australia. I. The genera Metacyclops, Mesocyclops, Microcyclops and Apocyclops (Crustacea Copepoda: Cyclopidae). Records of the Western Australian Museum 18: $67-76$

Pesce, G. L., De Laurentiis P. and Humphreys W. F. (1996b). Copepods from ground waters of Western Australia. II. The genus Halicyclops (Crustacea Copepoda: Cyclopidae). Records of the Western Australian Museum 18: 77-85.

Poore, G.C.B. and Humphreys, W.F. (1998). First record of Spelaeogriphacea from Australasia: a new genus and species from an aquifer in the arid Pilbara of Western Australia. Crustaceana 71: 721-742.

Watts, C.H.S. and Humphreys, W.F. (1999). Three new genera and five new species of Dytiscidae (Coleoptera) from underground waters in Australia. Records of the South Australian Museum 32: 121-142.

Watts, C.H.S. and Humphreys, W.F. (2000). Six new species of Nirridessus and Tjirtudessus (Dytiscidae; Coleoptera) from underground waters in Australia. Records of the South Australian Museum 33: 127-144.

Manuscript received 14 April 2000; accepted 11 October 2000.

Edited by M.S. Harvey. 